\title{
EFFECTS OF AN ACTIVE POCKMARK FIELD ON THE DISTRIBUTION OF HEAVY METALS OF SURFICIAL SEDIMENTS IN THE GULF OF PATRAS, GREECE J. RAVASOPOULOS ${ }^{1}$, G. PAPATHEODOROU ${ }^{1}$ AND J. KAPOLOS ${ }^{1}$
}

\begin{abstract}
Factor analysis carried out in thirteen sediment cores, collected from an active pockmark field area in the eastern part of the Gulf of Patras, discriminated a domestic sewage pollution factor, the $\mathrm{Mn} / \mathrm{Fe}$ oxides and the carbonate sedimentation. The increased content in sand, the low $\mathrm{C}_{\text {org }}$ content as well as the lack of $\mathrm{C}_{\text {org }} /$ heavy metals association follow a specific NW-SE transect in the centre of the surveyed pockmark field, suggesting pockmarks activity. This seems to control sedimentation and heavy metals distributions.
\end{abstract}

KEY WORDS: pockmarks, heavy metals, factor analysis, pockmark activity, geochemistry, Gulf of Patras.

\section{INTRODUCTION}

This paper deals with the distributions of several heavy metals in surficial sediments taken from pockmarks and the surrounding seafloor of an active pockmark field in the eastern Gulf of Patras. It is the first time such an attempt is being made, since there are no references dealing with geochemistry in active pockmark fields. The further aim of this study is to investigate the potential effects of pockmarks activity in the distributions of heavy metals in surficial sediments contained in the field, by applying a multivariate statistical analysis on the sediments grain size data and metals concentrations.

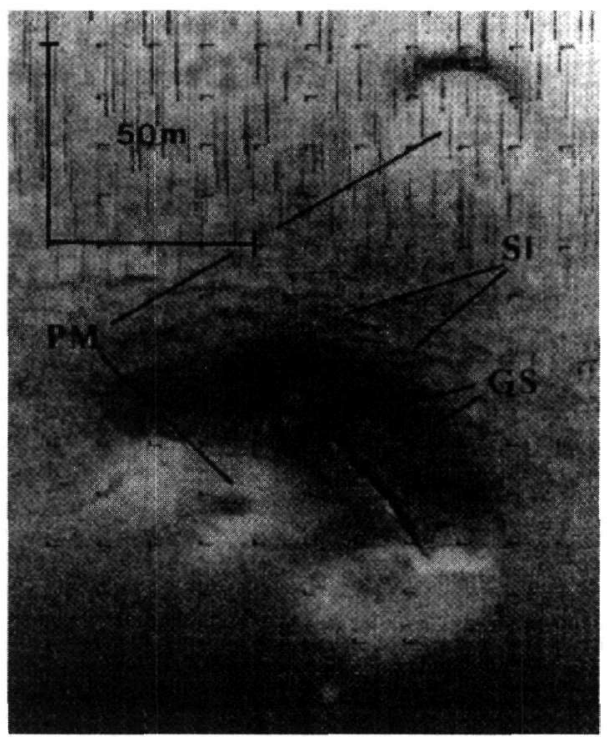

Figure 1. Side scan sonar image from the Gulf of Patras showing gas plumes (GS) rising in the water column from active pockmarks (PM). The circular step-like features (Sl) in the rim of the pockmark may indicate that the sidewalls are affected by slumping due to the release of gas.

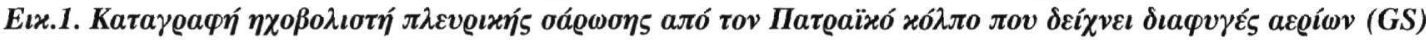

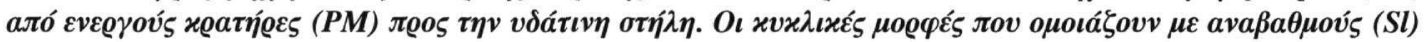

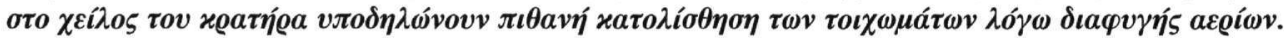

1. Laboratory of Marine Geology and Physical Oceanography, Geology Department, University of Patras, 261 10, Rio, Patras, Greece. Email: ethagefo@upatras.gr. 


\section{GEOLOGICAL SETTING}

The Gulf of Patras is an active tectonic trough with a W.NW - E.SE direction. The gulf is covered by Holocene sediments, which lie on Pleistocene depositions (Ferentinos et al., 1985). The Holocene and Pleistocene sediments of the gulf are gas-charged (Ferentinos, 1992; Papatheodorou et al., 1993; Hasiotis et al., 1996). The subsurface gas is mostly methane, biogenic in origin. These hydrocarbons migrate towards the seabed surface through the Holocene/Pleistocene interface, which seems to be the area of gas hydrocarbon accumulations (Papatheodorou et al., 1993). Gas hydrocarbons escape to the water column through faulty zones and/or pockmarks formed on the seafloor (Fig.1). Recently, Hasiotis et al. (1996) found a large active pockmark field in the eastern part of the gulf. Pockmarks varied in size and shape from 25 to $250 \mathrm{~m}$ in diameter and from 0.5 to $15 \mathrm{~m}$ in depth. This pockmark field was activated during the 14/7/1993 seismic event, releasing large amounts of gas in the water column.

\section{METHODS}

The bathymetric survey was carried out prior to coring, using a precision depths meter ODOM ECHOTRAC DF3200 MKII, equipped with a $200 \mathrm{kHz} / 2.75^{\circ}$ transducer. A Differential GPS, type TRIMBLE 4000 II RL-DL, with an accuracy of $\pm 1 \mathrm{~m}$ was used for positioning. Sediment cores were obtained with the use of a BENTHOS gravity corer. Thirteen (13) cores were collected from inside and outside the pockmarks (Fig.2). The top $2 \mathrm{~cm}$ of each core was subsampled and considered as surficial sample. Laboratory analyses consisted of grain size (Folk, 1974), organic carbon determination according to Gaudette et al. (1974) and heavy metals were extracted by bulk sediment digestion with the attack of $\mathrm{HCl}, \mathrm{HNO}_{3}$ and $\mathrm{HF}$, according to Thompson and Wood (1982). Digested samples were analysed for $\mathrm{Ca}, \mathrm{Fe}, \mathrm{Co}, \mathrm{Cu}, \mathrm{Mn}, \mathrm{Pb}$ and $\mathrm{Zn}$ with the use of a Perkin Elmer 3110 AAS. The concentration for each metal was derived by the equation given for the calibration curve for each metal.

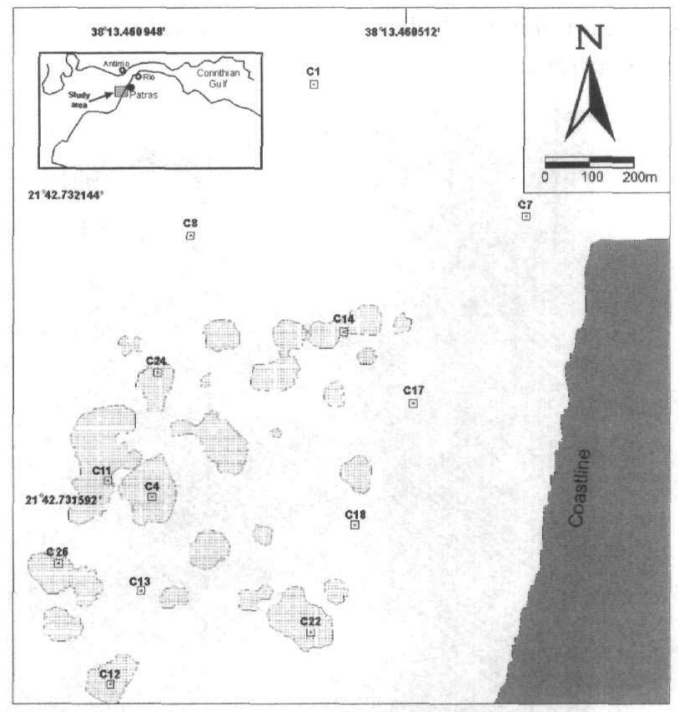

Figure 2. Map of the study area showing coring locations (dotted squares) in relation to pockmarks (stippled areas).

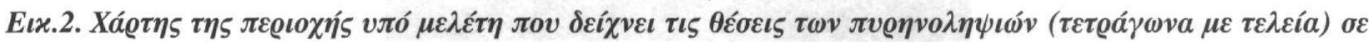

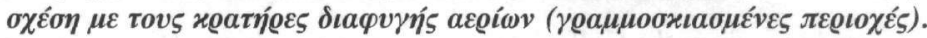

Factor Analysis (Davis, 1986), a multivariate statistical method, was applied to the grain size classes $(<-1 \mathrm{Z}$, (-1)-0Z, $0-1 \mathrm{Z}, \ldots, 9-10 \mathrm{Z})$ and geochemical $\left(\mathrm{Ca}, \mathrm{C}_{\text {org }}, \mathrm{Fe} \mathrm{Co}, \mathrm{Cu}, \mathrm{Mn}, \mathrm{Pb}\right.$ and $\mathrm{Zn}$ ) data. It provides the possibility to determine the geographical distribution of the resulting factors. The geochemical - geological interpretation of the factors gives an insight into the main processes that may control the distribution of the variables. The aim of $R$-mode Factor Analysis is to represent a large number of variables in the original data set by a significantly smaller number of 'factors', each of which is a linear function of the original variables.

a. Data matrix: A 13 rows ' 16 columns matrix was created on a spreadsheet. Rows corresponded to the number of samples and columns to the elements concentrations and grain size classes (variables). 


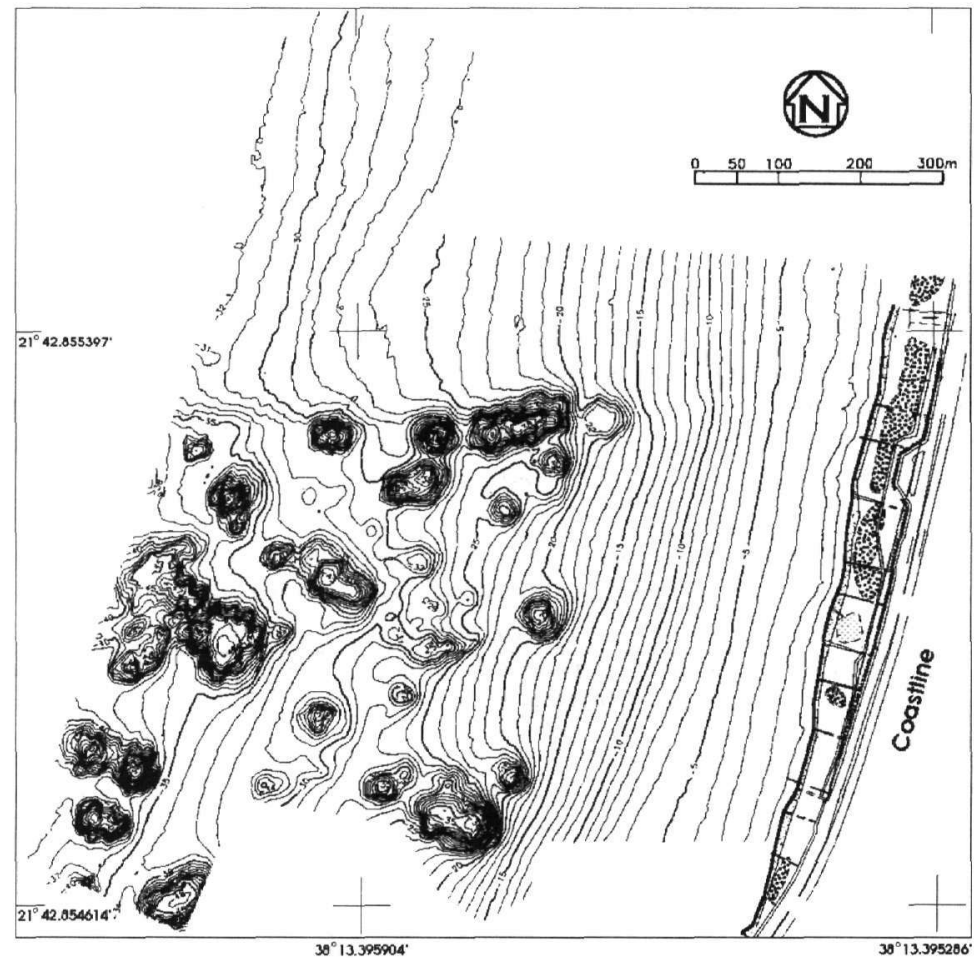

Figure 3. Detailed bathymetric map of the study area. Depths calculated from Mean Sea Level. Isobaths in metres. Major isobaths (thick lines) every $5 \mathrm{~m}$, minor (light lines) every $1 \mathrm{~m}$.

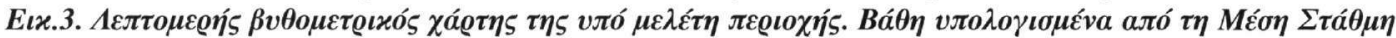

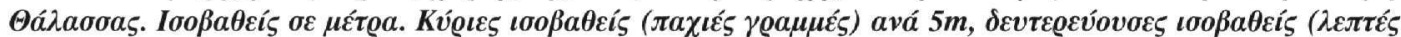

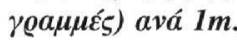

b. Correlation matrix: The correlation coefficient $(R)$ was used to measure the linear relationship between each pair of variables. A $16^{\prime} 16$ correlation matrix was resulted.

c. Initial factor matrix: The eigenvalues and corresponding eigenvectors of the correlation matrix were extracted. An initial factor matrix was computed using standard mathematical procedures. Eigenvalues account for the total variability variation explained by each factor. Each factor consists of as many coefficients (loadings) as the number of variables. The loadings represent the correlation between the factor and the original variables.

d. Selection of the number of factors: In order to reduce the complexity of the original data, the selection of an optimal $k$ number of factors, less than the $p$ original variables $(k<p)$, is required. There are no universally agreed upon criteria for the selection of the number of factors to be retained. There are many suggestions for selecting the optimum number of factors (amount of the cumulative variance, eigenvalues $>1$, scree plot) (Davis, 1986; Reyment and Joreskop, 1993), but the most straightforward solution is to retain as many factors as the ruling theory demands. The cut-off of the $k$ significant factors in the present study was based on the cumulative percentage of variance, which was accounted for by the $k$ factors, in conjunction with the clear-cut geochemical/granulometric meanings, which are represented by the factors. In this way, high communalities were achieved for each variable when $k$ factors were retained.

e. Rotation of factor axes: The simple factor matrix consists of simple factors that have a few high and many zero or near-zero loadings. Kaiser's Varimax orthogonal rotation method was applied to the initial unrotated factor loadings in order to achieve a simple structure (Kaiser, 1958).

f. Factor scores: Factor scores determine the 'amount' of each factor in each sample. The factor scores matrix was computed by multiplying the factor loadings for the variables times the original values of the variables and then combined these products to obtain a score for each sample. This step is important for the mapping of the geographical distribution of each factor. 


\section{RESULTS}

\section{Bathymetry}

A detailed bathymetric map of the study area (Fig.3) indicates several pockmarks on the seabed of the area. These pockmarks lie in the north-end part of the pockmark field discovered and surveyed by Hasiotis et al. (1996). The surrounding seafloor appears to be smooth with no particular morphological features.

\section{Grain size}

Table 1 shows the sediments contents in sand, silt and clay fractions, as well as their textural description according to Folk (1974). Generally, the sediments consist of fine materials. The spatial distribution of clay (Fig.4a) shows that it increases away from sample 14, which was taken inside a composite pockmark. Silt decreases away from sample 14 (Fig.4b) and sand exhibits a general shoreward-increasing gradient (Fig.4c). However, two local sand peaks appear at samples 22 and 24, which were taken inside pockmarks.

Table 1. Grain size fraction percentages and textural descriptions of the surficial samples analysed.

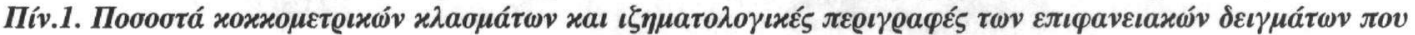

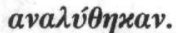

\begin{tabular}{|c|c|c|c|c|c|c|c|c|c|}
\hline $\begin{array}{l}\text { Sample } \\
\text { No. }\end{array}$ & $\begin{array}{l}\text { Clay } \\
\text { (z) }\end{array}$ & $\begin{array}{l}\text { Silt } \\
(\mathrm{z})\end{array}$ & $\begin{array}{l}\text { Sand } \\
(\mathrm{z})\end{array}$ & $\begin{array}{c}\text { Textural } \\
\text { description }\end{array}$ & $\begin{array}{l}\text { Sample } \\
\text { No. }\end{array}$ & $\begin{array}{l}\text { Clay } \\
(8)\end{array}$ & $\begin{array}{l}\text { Silt } \\
(z)\end{array}$ & $\begin{array}{l}\text { Sand } \\
(z)\end{array}$ & $\begin{array}{c}\text { Textural } \\
\text { description }\end{array}$ \\
\hline 1 & 40.7 & 56.6 & 2.7 & Mud & 14 & 7.8 & 90.4 & 1.9 & Silt \\
\hline 4 & 43.1 & 53.1 & 3.9 & Mud & 17 & 28.7 & 63.9 & 7.5 & Silt \\
\hline 7 & 30.5 & 50.0 & 19.6 & Sandy Mud & 18 & 39.4 & 56.3 & 4.3 & Mud \\
\hline 8 & 42.9 & 54.0 & 3.1 & Mud & 22 & 34.5 & 48.1 & 17.4 & Sandy Mud \\
\hline 11 & 45.0 & 54.2 & 0.8 & Mud & 24 & 22.3 & 62.1 & 15.7 & Sandy Mud \\
\hline 12 & 39.8 & 59.5 & 0.7 & Mud & 26 & 39.6 & 59.4 & 1.0 & Mud \\
\hline 13 & 40.6 & 55.7 & 3.7 & Mud & & & & & \\
\hline
\end{tabular}
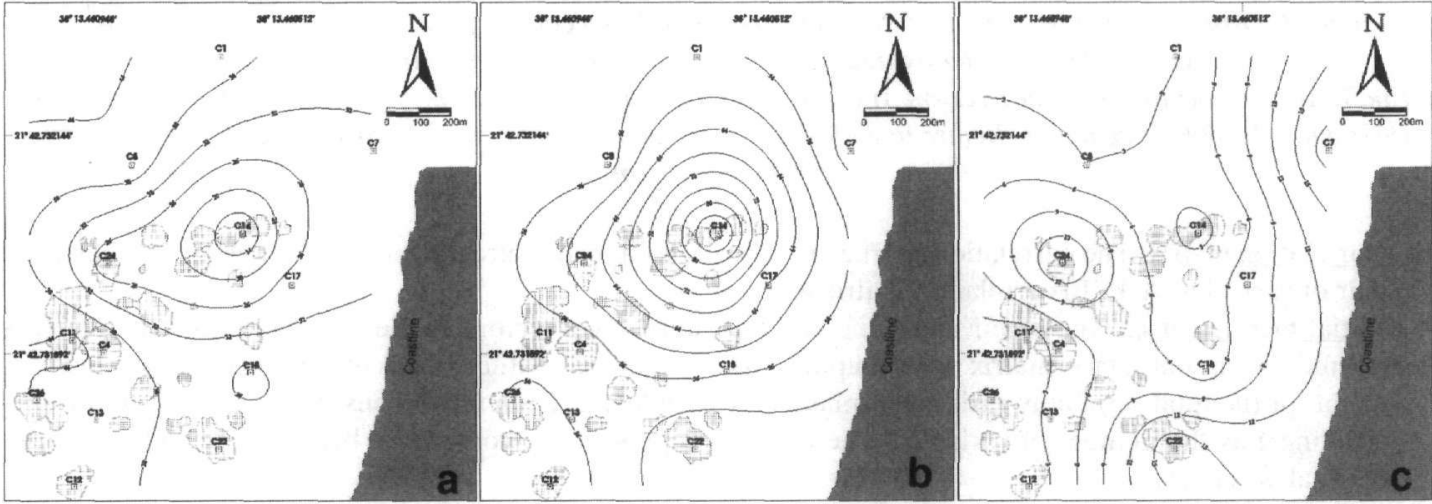

Figure 4. Maps of the study area showing cores locations (as in Fig.2) and the spatial distributions of clay (a), silt (b) and sand (c) in the surficial sediments. Contours represent sediment fraction content in \%. Stippled areas as in Fig.2.

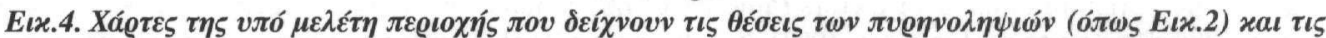

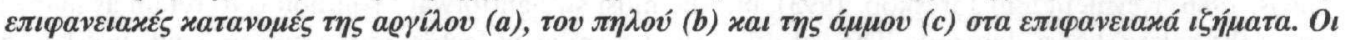

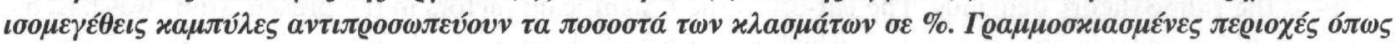

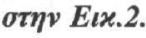

\section{Geochemistry}

The comparison of Table 1 and Table 2 shows that calcium occurs in higher concentrations where surficial sediments have higher silt content. Generally, there is a Ca-increasing gradient from the offshore to the nearshore surficial sediments. The spatial distribution of $\mathrm{C}_{\text {org }}$ (Fig.5) shows that it is detected in higher concentrations near-shore, particularly at the northern part of the studied area. Minimum $\mathrm{C}_{\text {org }}$ concentrations were found in the middle of the pockmark field. Numerous sewage pipes discharge untreated domestic wastes from the city of Patras along the coastline of the study area. The effect of Patras city sewage in the surficial sediments of the 
study area is quite evident by the fact that maximum $\mathrm{C}_{\text {org }}$ concentrations occur at the north of the study area (i.e. closer to Patras city).

Table 2. Concentrations of calcium (\%), organic carbon (\%) and heavy metals (Fe in \%; Co, Cu, Mn, Pb and $\mathrm{Zn}$ in $\mathrm{mgXkg}^{-1}$ (ppm)) analysed in the surficial sediments.

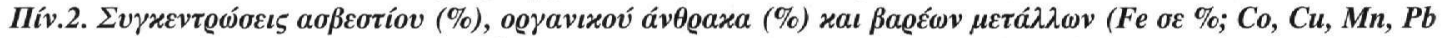

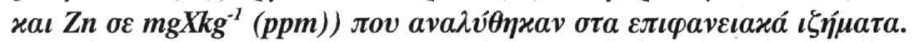

\begin{tabular}{|c|c|c|c|c|c|c|c|c|}
\hline Sample & No. $\mathrm{Ca}$ (\%) & $C_{\text {org }}(8)$ & Fe (\%) & Co (ppm) & Cu (ppm) & Mn (ppm) & $\mathrm{Pb}$ (ppm) & $\mathrm{Zn}$ (ppm) \\
\hline 1 & 5.6 & 1.1 & 2.8 & 35.4 & 60.7 & 743.8 & 98.5 & 152.1 \\
\hline 4 & 7.8 & 0.7 & 4.1 & 34.4 & 55.9 & 832.6 & 92.8 & 107.3 \\
\hline 7 & 5.2 & 1.2 & 2.5 & 31.9 & 53.8 & 589.5 & 74.8 & 78.8 \\
\hline 8 & 4.6 & 0.9 & 1.8 & 34.5 & 47.4 & 641.2 & 84.6 & 85.5 \\
\hline 11 & 8.5 & 0.9 & 5.0 & 52.9 & 65.5 & 966.0 & 82.6 & 108.8 \\
\hline 12 & 11.3 & 1.1 & 4.9 & 54.1 & 65.0 & 883.2 & 90.4 & 131.3 \\
\hline 13 & 10.1 & 1.2 & 3.9 & 44.5 & 64.5 & 883.2 & 100.1 & 105.3 \\
\hline 14 & 11.3 & 1.1 & 3.5 & 50.4 & 57.5 & 750.6 & 90.7 & 101.4 \\
\hline 17 & 11.6 & 1.3 & 3.4 & 66.3 & 81.4 & 798.6 & 105.3 & 128.3 \\
\hline 18 & 8.7 & 0.8 & 2.3 & 30.5 & 53.0 & 692.5 & 54.9 & 75.9 \\
\hline 22 & 9.0 & 1.0 & 3.1 & 48.4 & 57.3 & 804.0 & 70.9 & 79.4 \\
\hline 24. & 7.0 & 0.7 & 2.6 & 37.0 & 48.9 & 742.0 & 66.6 & 71.7 \\
\hline 26 & 6.0 & 0.9 & 2.6 & 32.6 & 43.7 & 844.2 & 64.5 & 86.2 \\
\hline
\end{tabular}

Fe concentrations in surficial sediments exhibit a decreasing gradient towards the city of Patras, while maximum Fe concentrations are noted in samples taken inside pockmarks. Cobalt shows a general decreasing concentrations gradient offshorewards. Maximum Co concentrations occur rather locally around sample 17. Another local peak occurs around sample 11 to the west of the pockmark field. $\mathrm{Cu}$ in the surficial sediments appears to increase from offshore to nearshore, showing maximum concentrations locally around sample 17. Enhanced $\mathrm{Cu}$ concentrations also seem to occur around samples 11 and 22 at the west and south parts of the area respectively, disturbing thus an even shoreward-increasing $\mathrm{Cu}$ distribution. Manganese increases in a NESW direction. In a wider geographical view, Mn increases from the surficial sediments near the city of Patras (NE) to the south. Maximum Mn values seem to be locally concentrated, rather than distributed. Three areas of maximum $\mathrm{Pb}$ concentrations lie at the $\mathrm{N}, \mathrm{E}$ and $\mathrm{SW}$ parts of the study area (samples 1, 17 and 13 respectively). Maximum $\mathrm{Zn}$ appears at the north and in nearshore sectors, showing a decreasing gradient to the south and offshore. In the pockmark field $\mathrm{Zn}$ distribution is random.

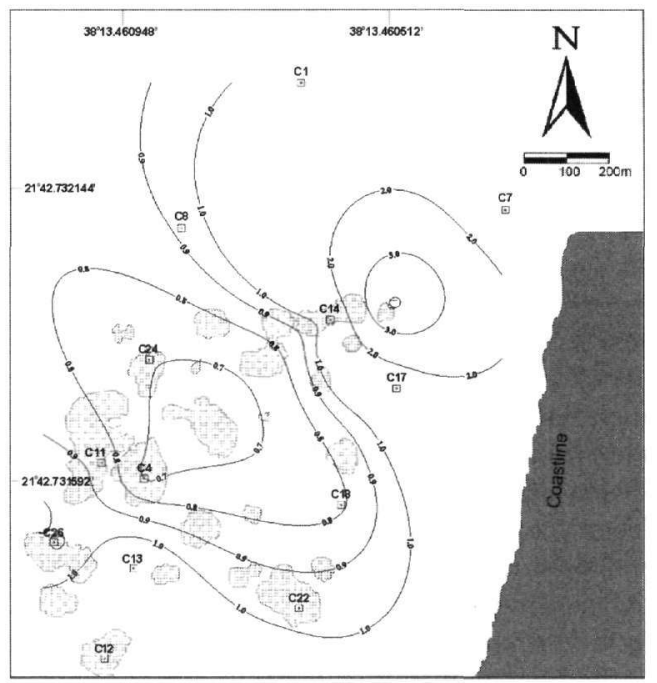

Figure 5. Map showing the $C_{\text {org }}$ content (\%) in the surficial samples. Stippled areas as in Fig.2.

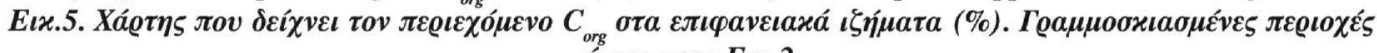

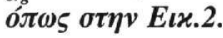




\section{Factor Analysis}

A 5-factors model accounts for the $85.3 \%$ of the total variance of the original variables (Table 3 ). The first two factors combine both geochemistry and granulometry, while the third is a pure geochemical factor. The last two factors are purely granulometric, explaining interrelationships between the grain size classes. The high communalities achieved (Table 4) suggest that the model is statistically significant. The Varimax rotated loadings for each factor extracted are shown in Table 4. Table 5 presents the scores of the extracted factors.

Table 3. Eigenvalues, individual and cumulative percentages of variance explained by each factor (R-mode) for the surficial samples.

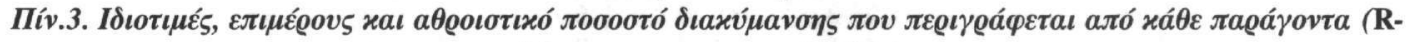

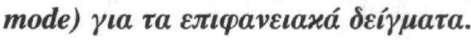

\begin{tabular}{cccc}
\hline Factor Eigenvalue & \multicolumn{2}{c}{$\begin{array}{c}\text { Percentage of } \\
\text { variance }(\mathrm{z})\end{array}$} & $\begin{array}{c}\text { Cumulative percentage of } \\
\text { variance }(\mathrm{z})\end{array}$ \\
\hline 1 & 5.89389 & 36.8 & 36.8 \\
2 & 3.07562 & 19.2 & 56.1 \\
3 & 1.98507 & 12.4 & 68.5 \\
4 & 1.46978 & 9.2 & 77.7 \\
5 & 1.21573 & 7.6 & 85.3 \\
$\vdots$ & $\vdots$ & $\vdots$ & $\vdots$ \\
16 & 0.00000 & 0.0 & 100.0 \\
\hline
\end{tabular}

Table 4. Varimax rotated factor loadings and related communalities for the 5-factors model (R-mode) selected for the surficial samples. Factor loadings are unitless.

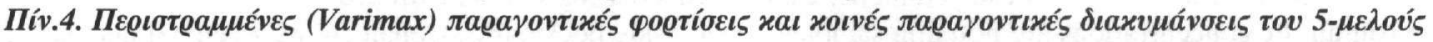

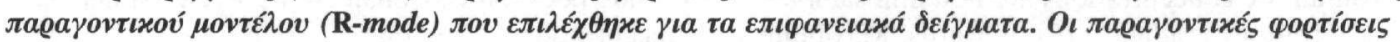

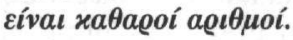

\begin{tabular}{ccccccc}
\hline Variable & Factor 1 & Factor 2 & Factor 3 & \multicolumn{1}{c}{ Factor 4 } & Factor 5 & Communalities \\
\hline $\mathrm{Ca}$ & 0.1164 & 0.3469 & 0.7856 & -0.0989 & 0.3751 & 0.90150 \\
$\mathrm{Co}$ & 0.4129 & 0.3308 & 0.7510 & -0.0329 & 0.0502 & 0.84750 \\
$\mathrm{C}$ org & 0.6956 & -0.2248 & 0.3718 & -0.3373 & -0.0629 & 0.79040 \\
$\mathrm{Cu}$ & 0.5251 & 0.2425 & 0.6779 & -0.2651 & -0.0697 & 0.86916 \\
$\mathrm{Fe}$ & 0.2405 & 0.8060 & 0.4210 & -0.0720 & 0.0400 & 0.89158 \\
$\mathrm{Mn}$ & 0.1408 & 0.9572 & 0.1599 & 0.0504 & 0.0360 & 0.96543 \\
$\mathrm{~Pb}$ & 0.8416 & 0.1586 & 0.2861 & -0.1628 & 0.0343 & 0.84292 \\
$\mathrm{Zn}$ & 0.7553 & 0.3376 & 0.1103 & -0.2650 & 0.0890 & 0.77473 \\
$<(-1)-3 \varnothing$ & -0.1816 & -0.5210 & 0.2775 & -0.0221 & -0.6822 & 0.84725 \\
$3-4 \varnothing$ & -0.2294 & -0.6638 & 0.2811 & -0.4874 & 0.2880 & 0.89276 \\
$4-5 \varnothing$ & 0.8644 & 0.1922 & 0.1730 & 0.1306 & 0.1151 & 0.84437 \\
$5-6 \varnothing$ & 0.0282 & 0.0583 & 0.2548 & 0.0793 & 0.7826 & 0.68792 \\
$6-7 \varnothing$ & -0.1248 & 0.2163 & -0.2145 & 0.9149 & 0.0794 & 0.95169 \\
$7-8 \varnothing$ & -0.2651 & 0.1842 & -0.7618 & 0.0478 & 0.1788 & 0.71878 \\
$8-9 \varnothing$ & -0.0246 & 0.4468 & 0.1835 & 0.1542 & -0.7772 & 0.86164 \\
$9-1 \varnothing \varnothing$ & -0.2271 & -0.1247 & 0.0433 & 0.9382 & -0.0575 & 0.95247 \\
\hline
\end{tabular}

Factor 1 accounts for the $36.8 \%$ of the total variance of the original variables (Table 3 ). High to moderate factor loadings were shown for $\mathrm{Pb}, \mathrm{Zn}, \mathrm{C}_{\text {org }}, \mathrm{Cu}, \mathrm{Co}$ and the 5-6Z grain size class (silt) (Table 4). This factor is a typical 'domestic sewage pollution' factor. Salomons and Forstner (1984) reported that these metals (among others) are indices of pollution in nearshore sediments. High positive factor scores were obtained for samples 1 and 17 (Table 5). The effect of Factor 1 in the surficial sediments in terms of geographic distribution is shown by the spatial distribution of the factor scores in Fig.6a. Generally, Factor 1 seems to have high scores in samples located in the SW and NE parts of the study area, the latter being closer to the city of Patras. Most of the surficial samples exhibiting high positive factor scores were collected outside pockmarks. The most striking observation in the spatial distribution of Factor 1 scores (Fig.6a) is the lack of $\mathrm{C}_{\text {org }}$ /metals association in the centre of the pockmark field. The pockmark field is dominated by negative factor scores, which occur for samples inside pockmarks, except for sample 18. The contribution of silt in the factor (Table 4) is justified by the fact that areas of moderate and/or high positive factor scores are dominated by enhanced contents in silt (Fig.6a). 
Table 5. Factor scores obtained for the 5-factors model (R-mode) applied for the surficial samples. Factor scores are unitless.

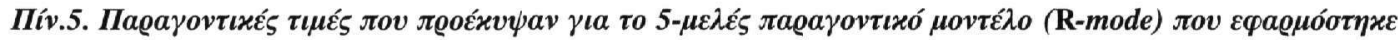

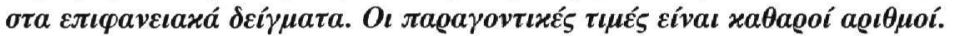

\begin{tabular}{crrrrr}
\hline Sample & Factor 1 & Factor 2 & Factor 3 & Factor 4 & Factor 5 \\
\hline 1 & 1.3739 & -0.2736 & -0.9337 & -0.4582 & -0.3923 \\
4 & -0.1949 & 0.8677 & -0.5085 & -0.2554 & -0.0602 \\
7 & 0.2581 & -1.7786 & -0.1926 & -0.3588 & -1.2165 \\
8 & -0.0214 & -1.0744 & -1.0403 & -0.3233 & -0.0619 \\
11 & -0.3360 & 1.9127 & 0.3621 & -0.1287 & -0.4374 \\
12 & 0.5569 & 1.1179 & 0.5648 & -0.1807 & 0.3422 \\
13 & 0.6488 & 0.5857 & 0.2543 & -0.0826 & -0.184 \\
14 & 0.2850 & -0.5956 & 1.0967 & 0.2345 & 2.3116 \\
17 & 1.4955 & -0.5110 & 1.3844 & -0.2037 & 0.0065 \\
18 & -2.2259 & -0.6151 & 0.0280 & -1.2352 & 1.0643 \\
22 & -1.1379 & 0.1648 & 0.9819 & -0.5156 & -1.7332 \\
24 & -0.7695 & -0.4305 & 0.2580 & 3.0569 & -0.3508 \\
26 & 0.0672 & 0.6299 & -2.2550 & 0.4508 & 0.6561 \\
\hline
\end{tabular}

Factor 2 accounts for the $19.2 \%$ of the total variance of the original data (Table 3 ). High positive loadings were resulted for $\mathrm{Mn}$ and $\mathrm{Fe}$, while a more moderate loading was observed for the 9-10Z grain size class (clay) (Table 4). This factor is interpreted as an $\mathrm{Mn} / \mathrm{Fe}$ oxides factor. The capability of $\mathrm{Mn}$ - and Fe-oxides to scavenge other trace metals is well documented (Goldberg, 1954; Cronan, 1969; Calvert and Price, 1977), but no heavy metals seemed to relate with $\mathrm{Mn}$ and $\mathrm{Fe}$ in the factor. Comparing Factors 1 and 2 with respect to metals affiliation, there seems to be a competition between the organic matter and the Fe/Mn oxides. Organic matter appears to dominate over the $\mathrm{Mn}-/ \mathrm{Fe}$-oxides with regard to metals adsorptive ability. Factor 2 has the greatest effects in samples 11 and 12, both of which come from inside pockmarks and show the highest positive factor scores (Table 5). The spatial distributions for Factors 1 and 2 (Fig.6a and $6 \mathrm{~b}$ respectively) indicate that the aforementioned competition between $\mathrm{C}_{\text {org }}$ and $\mathrm{Mn}-/ \mathrm{Fe}$-oxides, regarding metal bonding, may be more intense in the SW part of the study site. This particularly occurs in the surrounding area of samples 12 and 13, because both samples exhibited moderate to high positive factor scores for both factors.

Factor 3 explains the $12.1 \%$ of the total variance of the original variables (Table 3 ) and is a pure geochemical factor. The metals that contribute to the factor with high positive loadings are $\mathrm{Ca}$, $\mathrm{Co}$ and $\mathrm{Cu}$, while $\mathrm{Fe}$ exhibits a more moderate loading (Table 4). This third factor is interpreted as the carbonates fraction factor. The carbonates do not normally correlate well with heavy metals. The contribution of $\mathrm{Fe}$ in the factor may indicate that $\mathrm{Fe}$ is in lattice positions of the carbonate minerals and/or forms a coating around the carbonate grains under the Fe-oxide form, constituting an attraction pole for other metals as well, such as $\mathrm{Co}$ and $\mathrm{Cu}$, as the factor demonstrated. Caroll (1958) reported that Fe is deposited in the form of oxide or hydroxide and coats fine clay particles. High positive factor scores (Figure 6c) occurred for samples 14, 17 and 22 (Table 5), indicate that the particular surficial sediments are dominated by the carbonate fraction. This was also observed in the concentrations of $\mathrm{Ca}$ in surficial sediments, demonstrating high Ca content locally around samples 14 and 17 , as well as enhanced $\mathrm{Ca}$ in the surrounding area of sample 22.

Factors 4 and 5 account for the $9.2 \%$ and $7.6 \%$ of the total variance of the original variables respectively (Table 3). Both are pure granulometric factors. High positive loadings resulted for the $<(-1)-3 \mathrm{Z}$ and $7-8 \mathrm{Z}$ grain size classes in the fourth factor (Table 4). The fourth factor has an effect only in sample 24, which was the only one with a very high positive factor score (Table 5). Factor 5 is a bipolar factor with two associations that are inversely related. The grain size class that contributes most to the positive pole is 6-7Z (coarse silt) (Table 4). Two grain size classes comprise the negative pole of the fifth factor and these are the $3-4 \mathrm{Z}$ (coarse sand) and 9$10 \mathrm{Z}$ (clay) (Table 4). The positive factor pole has an effect in samples 14 and 18, which exhibited the highest positive scores, whereas the negative pole seems to have effect in samples 7 and 22 (Table 5). The pure granulometric nature of these last two factors does not provide helpful information regarding the distribution of heavy metals in surficial sediments. 

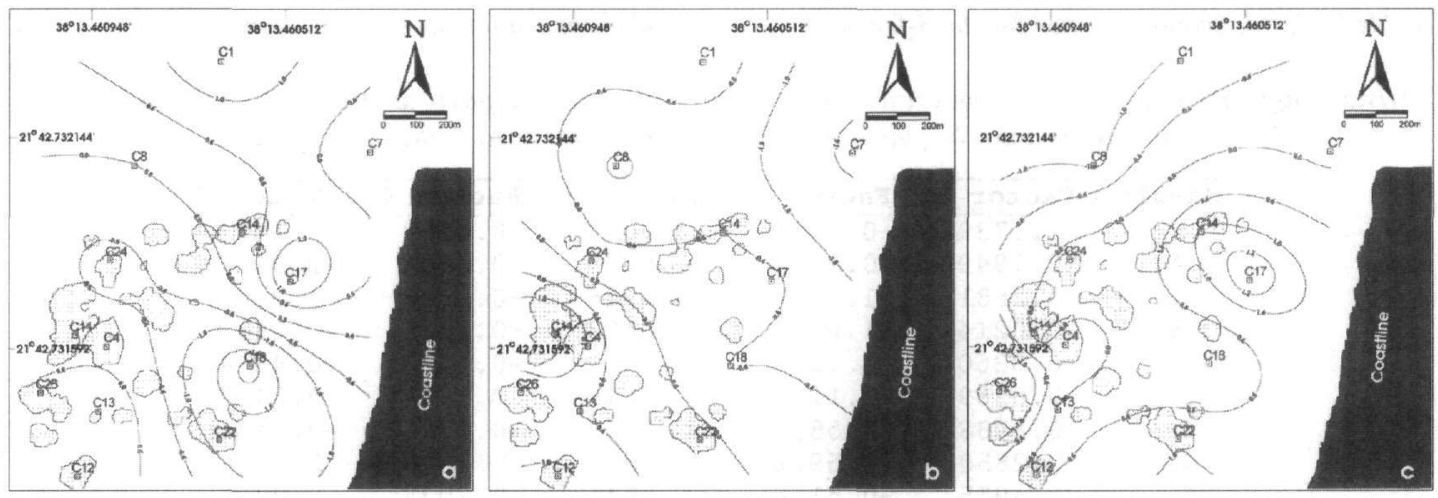

Figure 6. Spatial distributions of (a) Factor 1 scores, (b) Factor 2 scores and (c) Factor 3 scores in the surficial sediments. Contours represent factor scores, which are unitless. Stippled areas as in Fig.2.

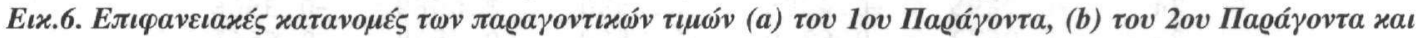

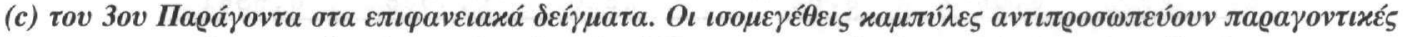

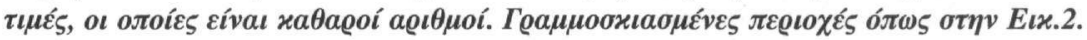

\section{CONCLUSIONS AND DISCUSSION}

Sediment samples analysed in the present study were sampled in an active pockmark field lying in the eastern part of the Gulf of Patras. Samples were taken from both inside and outside pockmarks. According to Hasiotis et al. (1996), the pockmark field was activated during a major earthquake event on $14^{\text {th }}$ July 1993 . The Gulf of Patras is a seismically active area, periodically giving earthquakes of great magnitudes (Papadopoulos and Lefkopoulos, 1993). Similar gas seepage triggered by earthquakes has also been documented at Malibu Point, CA (Clifton et al., 1971). Hasiotis et al. (1996) reported only one buried pockmark within the entire pockmark field during the time of their survey. This fact together with that the pockmarks are located in shallow waters, where sediment on the seafloor can be suspended and transported by the wave regime in the Gulf and therefore filling the pockmarks, suggest a long-term activity state of the field. Although there is evidence for the activity of the pockmark field as a whole, it cannot be pointed out which individual pockmarks are the active ones or which will be activated in the case of a triggering event in the future.

Grain size analyses showed that the surficial sediments in the study site consist of mud, sandy mud and silt. The coarser sediments seem to lie nearshore at the north end of the pockmark field. The distribution patterns of sand, silt and clay seem to be controlled by the presence of pockmarks that affects the general pattern of sediments distribution.

$R$-mode factor analysis applied for the surficial samples primarily discriminated the domestic sewage pollution factor, the Mn-/Fe-oxides phases in the surficial sediments and the carbonate sedimentation. Heavy metals in surficial sediments seem to have an affinity for the organic matter rather for the $\mathrm{Mn}$-/Fe-oxides. Organic matter dominates over the $\mathrm{Mn}$-/Fe-oxides in terms of metals adsorptive capability. Nevertheless, the strong association between $\mathrm{C}_{\text {org }}$ and heavy metals in surficial sediments does not seem to exist in the centre of the pockmark field under study. Oganic matter seems to control the distribution of heavy metals in surficial sediments, but no clear discriminations between 'inside' and 'outside pockmarks' samples can be implied. The combined study of the spatial distributions of the sand fraction, $\mathrm{C}_{\text {org }}$ and Factor 1 scores imply that pockmarks in the centre of the surveyed field may be active. The release of small but continuous amounts of gas re-suspends the fine sediments, which in turn are carried away by the current regime. Lastly, the carbonates seem to control sedimentation mainly in the nearshore surficial sediments.

In conclusion, the difference detected and interpreted between sediments inside and outside pockmarks in the Gulf of Patras lies in the ways heavy metals are linked with sediments fractions. The correlations made between sediments texture and geochemistry can be attributed to the pockmark field activity during gas release events. Although samples analysed were taken from both inside and outside pockmarks, in reality all samples locations are in the vicinity of the pockmark field. This means that samples analysed in the present study are all more or less affected by the activity of pockmarks. Therefore, it is possible that differences detected in their geochemistry - granulometry may be masked by the aforementioned fact. 


\section{REFERENCES}

CALVERT S.E. AND PRICE N.B. (1977). Geochemical variations in ferromanganese nodules and associated sediments from the Pacific Ocean. Mar. Chem., 5, pp. 43-74.

CARROLL D. (1958). Role of clay minerals in the transportation of iron. Geochimica Cosmochimica Acta, 14, p.1.

CLIFTON H., GREENE H., MOORE G. AND PHILLIPS R. (1971). Methane seep off Malibu Point following San Fernando earthquake. U.S. Geol. Surv. Prof. Pap., 733, pp. 112-112.

CRONAN D.S. (1969). Inter-element associations in some pelagic deposits. Chem. Geol., 5, pp. 99-106.

DAVIS J.C. (1986). Statistics and data analysis in geology. 2nd edition, J. Wiley \& Sons, New York, 656 pp.

FERENTINOS G. (1992). Oceanographical studies in the Gulf of Patras. Int. Rep., Lab. Mar. Geol. Phys. Oceanogr., $102 \mathrm{pp}$.

FERENTINOS G., BROOKS M. AND DOUTSOS T. (1985). Quaternary tectonics in the Gulf of Patras, western Greece. J. Struct. Geol., 7, pp. 713-717.

FOLK R.L. (1974). Petrology of sedimentary rocks. Hemphill, Austin, Texas, 182pp.

FORSTNER U. AND WITTMANN G.T.W. (1983). Metal pollution in the aquatic environment. 2nd edition, Springer - Verlag, Berlin, p. 475.

GAUDETTE H., FLIGHT W., TONER L., AND FOLGER D. (1974). An inexpensive titration method for the determination of organic carbon in recent sediments. J. Sedim. Petrol., 44, pp. 249-253.

GOLDBERG E.D. (1954). Marine Geochemistry. Chemical scavengers of the sea. J. Geol., 62, p.249.

HASIOTIS T., PAPATHEODOROU G. AND FERENTINOS G. (1996). A pockmark field in the Patras Gulf (Greece) and its activation during the 14/7/1993 seismic event. Mar. Geol., 130, pp. 333-344.

KAISER H.F. (1958). The varimax criteria for analytical rotation in factor analysis. Psychometrika, 23, pp. 187200.

PAPADOPOULOS G. AND LEFKOPOULOS G. (1993). Magnitude - distance relations for liquefaction in soil from earthquakes. Bull. Seismol. Soc. Amer., 83, pp. 925-938.

PAPATHEODOROU G., HASIOTIS T. AND FERENTINOS G. (1993). Gas charged sediments in the Aegean and Ionian Seas, Greece. Mar. Geol., 112, pp. 171-184.

REYMENT R. AND JORESKOP K.G. (1993). Applied factor analysis in the natural sciences. Cambridge University Press, London, $371 \mathrm{pp}$.

SALOMONS W. AND FORSTNER U. (1984). Metals in the hydrocycle. Springer-Verlag, Berlin, Heidelberg, $349 \mathrm{pp}$.

THOMPSON M. AND WOOD S. (1982). Atomic Absorption Spectrometry, Cantle E.J. (ed.), Elsevier, pp. 261284. 